\title{
ECONOMIC VALUE OF ECOSYSTEM SERVICES IN THE EASTERN ORE MOUNTAINS
}

\section{Ondřej Vojáček, Jiří Louda}

\section{Introduction}

The Eastern Ore Mountains landscape has its specific and unique character. In particular, it is due to several specific landscape elements and biotopes, which either do not exist in other locations or are not as frequent. These locally specific ecosystems include notably montane meadows, clearance cairns and natural streams. These ecosystems provide a number of ecosystem services, which should be taken into account in landscape management according to the latest scientific discourse (Albert et al., 2016; Braat \& de Groot, 2012; De Vreese et al., 2016; Farley, 2012; de Groot et al., 2010; Kenter et al., 2011; Květoň et al., 2014; Layke et al., 2012; Millenium Ecosystem Assessment, 2005; Palacios-Agundez et al., 2015; Primmer \& Furman, 2012). Another specific feature of the Eastern Ore Mountains is the region's history and the related unsatisfactory landscape management in the Czech Republic (Kučera, 1994; Radvanoský, 1993; Slezák, 2007). Wetlands and peat bogs were drained artificially and stream beds were canalised after the Second World War. After 1990, vast areas of montane meadows slowly began to fall to succession (overgrowing), resulting in a decrease in the extent of montane meadows. Clearance cairns, originally forming boundaries between fields or properties, began to overgrow too, or were swallowed up by forest. These original biotopes are slowly regaining attention today as they are producers of ecosystem services that may bring considerable benefits to people.

In connection with these ecosystems, the question arose how they should be managed and how much money should be spent on their maintenance (e.g., whether it is of any value for the inhabitants if meadows are regularly scythed to prevent overgrowing, or whether mountain streams should be revitalised). Such questions have to be dealt with on an ongoing basis as part of landscape management.

This paper focuses primarily on analysing the value of sociocultural ecosystem services of selected ecosystems (e.g., recreational services, provision of attractive conditions for living, aesthetic values of landscape), and represents the main conclusions of an extensive empirical survey aimed at estimating the recreational and aesthetic values as part of sociocultural ecosystem services of three locally specific ecosystems (montane meadows, clearance cairns, quasi-natural mountain streams) and their changes in connection with defined critical points of their management. The reason why the research was focused on the abovementioned ecosystem values is the tape of the landspace and its main usage, i.e. landspape greatly used for recreational purposes. Despite it is not possible to determine the share of sociocultural ecosystem services value on the total value of all ecosystem services in the location authors suppose that the share of estimated ecosystem services is significant. This consideration determined the study research focus. There would be different value distrribution among different ecosystem services and therefore also study focus in not very aesthetical agricultural land with minimum tourism.

Methodologically, the survey is based on an application of the stated preferences method (Bateman et al., 2002; Chapman et al. 1987), particularly the choice experiment method (Kenter et al., 2011; Moravčík, 1984; Vojáček \& Pecáková, 2010) and the contingent valuation method. The choice experiment yields more validity of the two methods, which is why the rest of this paper only presents the choice experiment results, data analysed using the Nlogit 4 software (the contingent valuation method was only used to identify the willingness 
to pay to prevent overgrowing of montane meadows; the result estimate is close to that from the choice experiment method). Several hypotheses for each ecosystem, specified below, were connected to the research objectives. To some degree, this research follows up on papers dealing with factors of customer satisfaction in tourism in general, such as Půlpánová and Simová (2012), as well as aspects of sustainable rural tourism, such as Šimková (2007; 2008).

The goal of the research in this paper is not to develop or discuss methods leading to estimates of economic value of non-market goods (there is a vast body of literature on that issue; for discussion of estimating values using choice experiment in various types of models, see e.g. (Vojáček \& Pecáková, 2010); the starting point for these methods in general is neoclassical environmental economy and its argument of economic efficiency in environmental policy, for more, see e.g. (Kotíková, 2006; Slavík, 2007; Slavíková et al., 2011; Vejchodská, 2015). With respect to the focus of the periodical and its regional location, the goal of the paper is to apply economic theory and econometric procedures to an estimate of values and their subsequent discussion, including potential economic and political recommendations for landscape management.

\section{Economic Value of Ecosystem Services in an International Context}

In the recent decade, the issue of ecosystem services has become a strong topic both in the academia and in public administration and environmental policy and landscape management makers in advanced countries. The concept of ecosystem services focuses on (i) identification of utilities arising from undamaged ecosystems, and (ii) methods of reflecting these utilities in decision-making processes of a market economy. The objective, among others, is that ecosystem services freely available in nature remain preserved and deterioration of natural living conditions is prevented.

The concept of ecosystem services is thus beginning to form a framework for practical solution of environmental problems occurring due to excessive stress of selected ecosystems. It significantly enriches the decision-making processes in society by introducing ecosystem services in an intelligible way to entities in national economy and politics, as well as professional and lay public, thus helping integrate economic and scientific findings for subsequent application of these findings in practical landscape management and spatial planning processes (Braat \& de Groot, 2012; de Groot et al., 2010) and implementation of sustainable development principles in practice at the local level (Květoň et al., 2014). According to Bateman et al. (2013), the landscape provides a wide range of valuable ecosystem services, but this value is often ignored in spatial planning decision-making processes, and it is therefore necessary to introduce the concept of ecosystem services to policy-makers' economic decision-making (similar conclusion have been reached by (Farley, 2012; Kenter et al., 2011; Layke et al., 2012; Primmer \& Furman, 2012).

The literature (e.g., Millenium Ecosystem Assessment, 2005) classifies ecosystem services into four basic categories: (i) supporting, (ii) provisioning, (iii) regulating, and (iv) (socio)cultural; each ecosystem typically provides the full range of services falling under the different categories. Sociocultural ecosystem services, on which this paper focuses, include, among others, recreational and tourist opportunities, inspiration for culture, art and design, the educational function, cultural heritage, provision of attractive conditions for living of inhabitants, and aesthetical values of the landscape. Currently abroad, the issue of cultural ecosystem services provided by landscape and their valuation are intensively discussed in many scientific papers, e.g. Bryce et al. (2016), Dickinson and Hobbs (2017), Lupp et al. (2016), Rewitzer et al. (2017), Small et al. (2017) or Stalhammar and Peresen (2017). Tengberg et al. (2012), and Chan et al. (2012) have proposed that methods of valuating cultural heritage and identity in landscape be integrated into ecosystem service valuation and thus help inform public policy-makers and urban designers in landscape and environmental management processes. Gee and Burkhard (2010) discuss the issue of cultural ecosystem services in connection with the rapid increase in so-called wind farms in Germany. Ruijs et al. (2013) deals with the relationship between cultural ecosystem services and the other categories of ecosystem services in 18 Central and Eastern European countries, focusing on trade-offs (compromises) that have to be made 
in decision-making processes within landscape management when handling prioritisation of certain ecosystem services on which the environmental and regional policy will focus with priority.

\section{Specific Ecosystems and Biotopes of the Eastern Ore Mountains in Relation to the Research Hypotheses}

Within our survey, attention was paid to three specific ecosystems that form the characteristic features of the Eastern Ore Mountain landscape and lend the location a specific character. They are namely montane meadows, natural or quasi-natural streams, and clearance cairns. The clearance cairns in particular represent a relatively unique landscape element, which is only seen exceptionally in other parts of the Czech Republic and its extent (hundreds of kilometres on either side of national border) makes the Eastern Ore Mountains a highly exceptional area.

\subsection{Montane Meadows}

Forest stands are more common in the natural conditions of the Eastern Ore Mountains (notably the elevation and latitude), so the existence of the montane meadows in the area is exceptional in itself (Moravčík, 1994). The montane meadows make the landscape unique for its openness, connected with a large number of vistas of the country, which increase its attractiveness for visitors, and are therefore a source of utility.

Above all, the montane meadows are a source of aesthetic and recreational values for visitors: vistas of the country and diversely flowering meadows in May and June. The survey therefore focused on the aesthetic values of the montane meadows. If the aesthetic and recreational value of the mountains meadows is to be preserved, then natural succession - gradual overgrowing with shrub and tree seedlings - has to be prevented. To this end, they have to be either regularly scythed or grazed by livestock.

The attention in the survey was therefore focused on three possible scenarios of montane meadow management: (i) scythed and flowering meadow, (ii) grazed and nonflowering meadow, and (iii) overgrowing montane meadow. Subsequently, we identified what value visitors to the Ore Mountains attach to these possible forms of montane meadows.

The research hypothesis relating to the montane meadows was that people would be indifferent between flowering meadows and meadows used for grazing livestock. The other hypothesis was that people would have negative preferences towards overgrowing not maintained - meadows.

\subsection{Clearance Cairns}

The use of deforested areas for agriculture gave rise to another locally highly specific biotope, known as clearance cairns. Their origination is associated with the removal of large quantities of stones from farmed fields during the agricultural work of the past centuries. It has resulted in stone lines, 2-4 metres wide and approx. $1 \mathrm{~m}$ high, running through the country for dozens to hundreds of metres. In their present form, the clearance cairns belong among the cultural landscape biotopes rich in plant species.

As with the montane meadows, this part of the research focused on quantifying the economic value of the clearance cairns, specifically their aesthetic and recreational function. Like the montane meadows, the clearance cairns have to be maintained (periodically trimmed in particular), otherwise they overgrow gradually and progressively disappear from the landscape as a visible element. The research therefore focused on whether people are aware of the existence of the clearance cairns, whether they wish to have them preserved in the landscape, and above all, what economic value the attach to the clearance cairns not overgrowing, meaning that their aesthetic and recreational function remains preserved. However, it was assumed that people would not attach a significant value to this landscape element and, in line with that, our hypothesis was that their willingness to pay for clearance cairns not overgrown would be statistically insignificant.

\subsection{Quasi-Natural Mountain Streams}

Another biotope on the economic value of which this paper focuses is watercourses, or more specifically, quasi-natural mountain streams. They are such watercourses that are not at all or only minimally regulated and are characterised by quasi-natural aquatic and riparian vegetation, varying flow rates as well as diverse bed and bank structures. These 
watercourses in the Eastern Ore Mountains were largely regulated in the latter half of the $20^{\text {th }}$ century: straightened, their beds reinforced using stone or concrete, their depth unified, etc. There has been a noticeable trend of revitalising watercourses. Such revitalisation projects are very costly.

Our goal was therefore to find out whether visitors value more a revitalised mountain stream than a regulated watercourse, and whether revitalisations are thus a meaningful policy also from the point of view of tourism and recreation. The research hypothesis here was that the willingness to pay will be statistically more significant for quasi-natural streams than for artificial ones.

All the three biotopes studied require a relatively costly type of landscape management in order to be preserved in their quasi-natural form and provide their natural ecosystem services. With the montane meadows and clearance cairns, this involves chiefly removal of undesired plant species and regular scything; the montane meadows require scything only in certain seasons. Failing that, these biotopes will gradually fall to succession. Analogously, the transformation of artificially regulated mountain watercourses to quasi-natural streams will require high investment costs.

\section{Methodology}

The analysis of preferences of visitors to the Eastern Ore Mountains and identification of their willingness to pay for a certain type of condition/management of the ecosystems in question utilised the choice experiment method. This method was first exploited in environmental economy and then elaborated on in the early 1990s; it was applied chiefly in psychology, marketing research and travel behaviour studies from the 1960s. By nature, the choice experiment puts the respondent in a situation simulating their possible real market behaviour if a market for the goods in question really existed (see below). This reduces some potential systemic research errors such as strategic bias, where a respondent deliberately states a different value of their preferences in the contigent valuation method in order to influence the research results in a direction that suits them.

\subsection{Theoreticcal Foundation for the Choice Experiment}

The choice experiment is based on Lancaster's consumer choice theory (Lancaster, 1966) and the random utility model (RUM) (Manski, 1977; Phaneuf \& Smith, 2005). The choice experiment can be used to determine the non-market value of changes in environmental goods (e.g., change in quality of a good). According to Lancaster's approach to the consumer theory (Lancaster, 1966), consumers derive their utility not from a product as such but rather from attributes that constitute the good/product. Any product can be described by means of its attributes.

The application of a choice experiment requires the performance of an empirical survey in which several different products, described by means of their attributes, are offered to the respondent to choose from. One of the attributes is always the price of the product or a similar expression of its value (such as the travel distance, travel costs, entrance fee). The consumer then decides among options that differ in their price and level of other attributes. One of the options offered always has to be an opt-out/status quo, i.e., a situation where no change in the costs occurs or where the respondent simply does not choose any of the products/alternatives offered (Steer Davies Gleave, 2000).

Afterwards, econometric models (see below) are applied to estimate the strength of the influence of the different attributes and their levels on the respondents' decisions (or likelihood of choosing a product) - in our case, how the likelihood of a respondent's choice of option 1 over option 2 is influenced by the fact that either option refers to different quality/form of the mountain streams/montane meadows/ clearance cairns.

In addition, the choice experiment builds on the random utility theory (McFadden, 1974), which is based on the hypothesis that individuals decide based on both the attributes of the options used in the choice experiment (objective component) and a certain degree of randomness (random component). This random component originates either as a consequence of the randomness in the respondent's preferences or because the choice experiment attributes do not cover the full range of the respondent's preferences towards the good being examined (Freeman, 2003; Haab \& 
McConnell, 2003). The utility function of an option in a choice experiment can be written as:

$$
U_{i}=V_{i}+e_{i}
$$

where $U_{i}$ is the unobservable total utility, $V_{i}$ is the observable objective component of the utility, and $e_{i}$ is the random component. If an individual prefers option $i$ to option $j$, then $U_{i}$ has to be greater than $U_{j}$. Based on repeated observations, it can therefore be examined how the levels of different attributes influence the likelihood of choosing a concrete option.

The value estimation makes use of various multinomial logit regression models (see Vojáček \& Pecáková, 2010 for more). This paper presents estimates using a multinomial logit (MNL) model. The model is based on the assumption that the random component $\varepsilon_{i j}, j=1,2, \ldots, J$, has a so-called Gumbel distribution (or a type I extreme value distribution) with a cumulative distribution function defined as:

$$
F\left(\varepsilon_{i j}\right)=\exp \left[-\exp \left(\varepsilon_{i j}\right)\right]
$$

and a spread of $\pi^{2} / 6$. If the random variables are distributed identically and independently of one another (so-called IID assumption) and have a Gumbel distribution, then their difference has a logit distribution (see Agresti, 2013; McFadden, 1974 and Lancaster, 1966 for more).

The likelihood of a respondent $i$ choosing an option $\mathrm{j}$ can then be written as:

$$
\pi_{i j}=\frac{\exp \left(V_{i j}\right)}{\sum_{j} \exp \left(V_{i j}\right)}=\frac{\exp \left(\mathbf{x}_{i j}^{\prime} \boldsymbol{\beta}\right)}{\sum_{j} \exp \left(\mathbf{x}_{i j}^{\prime} \boldsymbol{\beta}\right)},
$$

where $x_{i j}$ denotes the values explaining the variables of the respondent $i$ and the choice $j$ (Steer Davies Gleave, 2000).

The IID assumption is usually tested using the Hausman-McFadden test (Hanley et al., 2001; McFadden, 1974). The test criterion has a chi-square distribution with a number of degrees of freedom equalling the number of the estimated parameters. The model suitability is usually measured using a statistic based on the log-likelihood function (e.g., Agresti, 2013). Here, the frequently used McFadden statistic is quoted:

$$
D_{M F}=\frac{\ln L_{0}-\ln L_{E}}{\ln L_{0}},
$$

where $L_{0}$ is the value of the likelihood function with only a constant, and $L_{E}$ is the value of the function with the estimated model. The statistic interpretation is somewhat different from that in linear models: its values are typically lower; the pseudo R-squared values between 0.3 and 0.4 correspond approximately to the $\mathrm{R}$-squared value of linear regression models between 0.6 and 0.8 , which has to be borne in mind when assessing the information capacity of the model.

Since price is always one of the attributes in a choice experiment (albeit expressed variously), an estimation of the willingness to pay for a change in the attribute level can be made based on the trade-off between the price and the level of each attribute. The estimate is made as follows (Hanemann, 1984):

$$
W T P_{\triangle X}=\Delta X \beta / \gamma
$$

where $\Delta \mathrm{X}=\mathrm{X}_{1}-\mathrm{X}_{0}$ (change of level of attribute $X), \beta$ is the estimated regression coefficient of the attribute level, $Y$ is the regression estimate of the price attribute.

\subsection{Study Population, Data Collection Strategy}

The study population was visitors to the Eastern Ore Mountains of age and of Czech nationality. Individual data were collected by means of an enquiry. The principal data collection was done in July 2013. Two rounds of pilot pre-survey (15 and 40 respondents respectively) were done on two different dates in June 2013. The pre-survey tested the questionnaire, which was adjusted in the progress. The data collection places and strategy were tested, as well as the length of the questionnaire in relation to the data collection strategy. The length of the questionnaire was reduced several times with respect to the maximum tested interview length of 15 minutes, which was acceptable to the respondents.

The enquiry was done on-site in two locations of the Eastern Ore Mountains: Komárí Vížka and Lesná. Face-to-face interviews were conducted by 9 trained interviewers and the completion of a questionnaire took usually 12 to 15 minutes. The survey resulted in 260 completed questionnaires for the contingent valuation method and 216 for the choice experiment. The reason for the different numbers of usable questionnaires is that the data from the second pre-survey could be used 


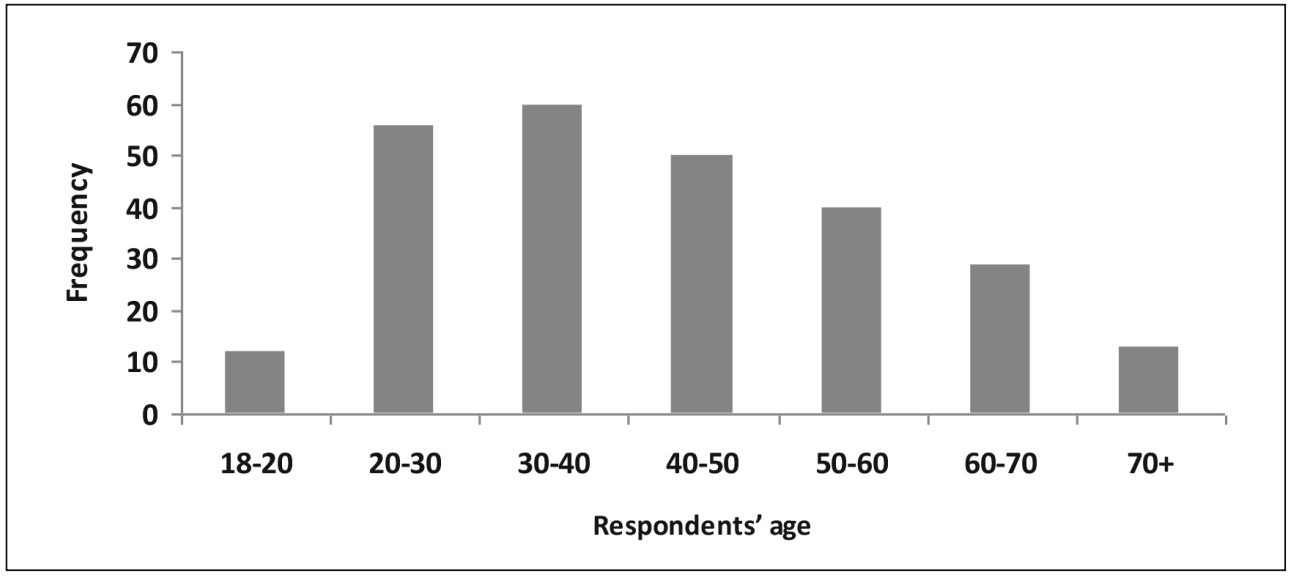

Source: own

for the contingent valuation method as well, whereas only the data from the main collection were usable for the choice experiment (the reason being the adjustment of the choice experiment between the pre-survey and the principal collection, making it impossible to use the choice experiment data from the presurvey). The rejection rate was $15 \%$. All the Czech visitors present in both data collection places during the data collection were interviewed in the data collection places.
Fig. 1 shows the respondents' age. A total of $50 \%$ of the respodents were under 40 years of age.

Tab. 1 shows the respondents' answers to the question "Please name the municipality where you currently live". The majority of the respondents live within $50 \mathrm{~km}$ of the data collection places.

\subsection{Choice Experiment Design}

Based on the research objectives (economic valuation of selected ecosystem services in

\section{Tab. 1: Names of municipalities where respondents live}

\begin{tabular}{l|c|c}
\multicolumn{1}{c|}{ Place of residence } & Number & Distance in $\mathbf{~ m m}$ \\
\hline Jirkov & 11 & 14 \\
\hline Děčín & 11 & 36 \\
\hline Chomutov & 16 & 21 \\
\hline Praha & 18 & 124 \\
\hline Most & 20 & 29 \\
\hline Teplice & 22 & 12 \\
\hline Ústí nad Labem & 31 & 24 \\
\hline Other locals & 45 & within $50 \mathrm{~km}$ \\
\hline Other visitors & 28 & more than $50 \mathrm{~km}$ \\
\hline
\end{tabular}


Tab. 2: Attributes and their levels in the choice experiment

\begin{tabular}{l|l}
\multicolumn{1}{c|}{ Attribute } & \multicolumn{1}{c}{ Levels } \\
\hline Meadows & - Flowering or not flowering \\
& - With farm animals or without animals \\
& - Overgrowing or not overgrowing \\
\hline Clearance cairns & - Not overgrown \\
& - Overgrown \\
\hline Streams & - Natural \\
& - Artificial \\
\hline Travel costs & - CZK 400 \\
& - CZK 800 \\
& - CZK 1,100 \\
\hline
\end{tabular}

the location) and in close cooperation with biologists, the choice experiment used the following attributes and their levels (Tab. 2).

The reasons for the above choice experiment design are as follows. For the montane meadows, the research objective was to find out whether people distinguish among various appearances of meadows (which have differing values in terms of ecosystem services), namely flowering meadows, overgrown meadows and meadows used for grazing farm animals. As is evident from Tab. 2, the levels of the attributes correspond with these objectives.

As for the clearance cairns, it was examined whether people distinguish between maintained clearance cairns (i.e., not overgrown) and clearance cairns that suffer progressive overgrowing - succession. The choice experiment attribute was accordingly specified at two levels: overgrown and not overgrown clearance cairns.

As for the mountain streams, it was analysed whether people have different utility from natural (quasi-natural) streams and artificial streams (this is reflected in the two levels of the attribute: artificial stream and natural stream). Each of these attribute levels is associated with both a different aesthetic function and a different quality of functions as part of ecosystem services (e.g., retention of water in landscape, habitats for wild animals).

The payment vehicle chosen was one-way travel costs for a weekend-long trip per person, excluding depreciation of the transport vehicle (Henscher, 1994; Parsons 1993). The amounts of the travel costs were tested in the pilot surveys and were then adjusted for the main data collection. To make the attribute easily intelligible in the choice experiment, one of the first questions of the questionnaire focused on having the respondent think about what travel costs they see as reasonable (the actual question was: "What amount of travel costs of a weekend-long trip is reasonable for you? Understand them as one-way costs per person of only the fuel/ticket, that is, excluding things such as vehicle depreciation."). As a result of this, respondents worked with pre-thought costs during the choice experiment as such.

A main-effect orthogonal design was used for combinations of options (see Freeman, 2003; Greene, 2007 for details). A respondent was asked to choose on of three options: location 1 , location 2 (described by means of attributes and their levels), or reply that they would not visit either location (opt-out option, necessary for bringing the survey in line with the welfare theory). Each respondent made nine choice in a row. The pilot survey showed that respondents are capable of managing nine choices in a row cognitively with the given choice experiment design (see e.g. Bateman et al., 2002 for a discussion of the number of choices).

Tab. 3 shows an example of a choice from the choice experiment. In the survey, the choices were characterised primarily with an appropriate photograph for each attribute (i.e., 6 photos on one A4 page for the below choice), so that the decision problem was considerably easier for the respondents compared with the verbal description below.

\section{Empirical Survey Results}

The remaining part of the paper presents the estimates made using the multinomial logit 
Tab. 3: Example of a choice in the choice experiment

\begin{tabular}{l|c|c} 
& Location 1 & Location 2 \\
\hline Attribute & Attribute value & Attribute value \\
\hline One-way travel costs & 400 & 1,100 \\
\hline Meadows & $\begin{array}{c}\text { Non-flowering } \\
\text { With farm animals } \\
\text { Not overgrown }\end{array}$ & $\begin{array}{c}\text { Flowering } \\
\text { Without farm animals } \\
\text { Not overgrown }\end{array}$ \\
\hline Cairns & Not overgrown & Overgrown \\
\hline Stream & Natural & Artificial \\
\hline
\end{tabular}

Source: own

model (MNL), applied in analysing discrete type data (Train, 2009). This type of regression analysis enables modelling of likelihood of the choice of a specific location defined in the choice experiment as a function of the levels of attributes used in the choice experiments for the location, or a function of some other variables in the questionnaire that can be put into interaction with the variables demonstrated by the attribute levels.

The explanatory variables (attribute levels) used in the model were as follows (see Tab. 4).

Tab. 5 presents the parameter estimates using the MNL model.

As is evident from Tab. 5, all the model parameters are significant at the $1 \%$

\section{Tab. 4: MNL model; explanatory variables}

\begin{tabular}{l|l|c}
\multicolumn{1}{c|}{ Variable } & \multicolumn{1}{c}{ Variable description } & Variable values \\
\hline Clearance cairns not overgrown & Clearance cairns not overgrown & $1=$ yes; $0=$ no \\
\hline Natural streams & Natural streams & $1=$ yes; $0=$ no \\
\hline Meadows with farm animals & Meadows with farm animals & $1=$ yes; $0=$ no \\
\hline Overgrown meadows & Overgrown meadows without farm animals & $1=$ yes; $0=$ no \\
\hline Travel costs & One-way travel costs & $400 ; 800 ; 1,100$ \\
\hline Opt_out & Substitute variable for the opt-out option & $0=$ no, $1=$ opt_out \\
\hline
\end{tabular}

\section{Tab. 5: MNL model; parameter estimates}

\begin{tabular}{l|r|r|r|r}
\multicolumn{1}{c|}{ Variable } & \multicolumn{1}{c|}{ Coefficient } & $\begin{array}{c}\text { Standard } \\
\text { Error }\end{array}$ & \multicolumn{1}{c|}{ b/St.Er. } & \multicolumn{1}{c}{ P[|Z|>z] } \\
\hline Clearance cairns not overgrown & $0.780^{* * *}$ & 0.680 & -6.159 & 0.000 \\
\hline Natural streams & $0.617^{* * *}$ & 0.079 & 8.639 & 0.000 \\
\hline Meadows with farm animals & $-0.569^{* * *}$ & 0.090 & -22.115 & 0.000 \\
\hline Overgrown meadows & $-0.376^{* * *}$ & 0.095 & -25.703 & 0.000 \\
\hline Travel costs & $0.001^{* * *}$ & 0.001 & -14.335 & 0.000 \\
\hline OPT_OUT & $-2.750^{* * *}$ & 0.122 & -22.463 & 0.000 \\
\hline
\end{tabular}

Note: ${ }^{* * *},{ }^{* *},{ }^{*}=1 \%, 5 \%, 10 \%$ significance level 
significance level and have the expected signs (except the clearance cairns, where we excepted a statistically insignificant estimate of the regression coefficient). People during recreation prefer flowering meadows; among the other options, they prefer meadows with grazing animals to overgrowing meadows. They have negative preferences towards artificial streams and the same applies to overgrown cairns; therefore, they clearly prefer clearance cairns not overgrown and quasi- natural streams. Naturally, people prefer lower travel costs to higher travel costs. The loglikelihood function has a value of $-2,305$. The model is statistically significant with an RsqAdj of 0.0667 .

Based on the estimate, the willingness to pay was calculated as the trade-off between the regression estimate of the attribute level and the estimate of the travel cost coefficient. The values are shown visually in Fig. 2 .

\section{Fig. 2: Marginal willingness to pay for an attribute change (in 2013 CZK)}

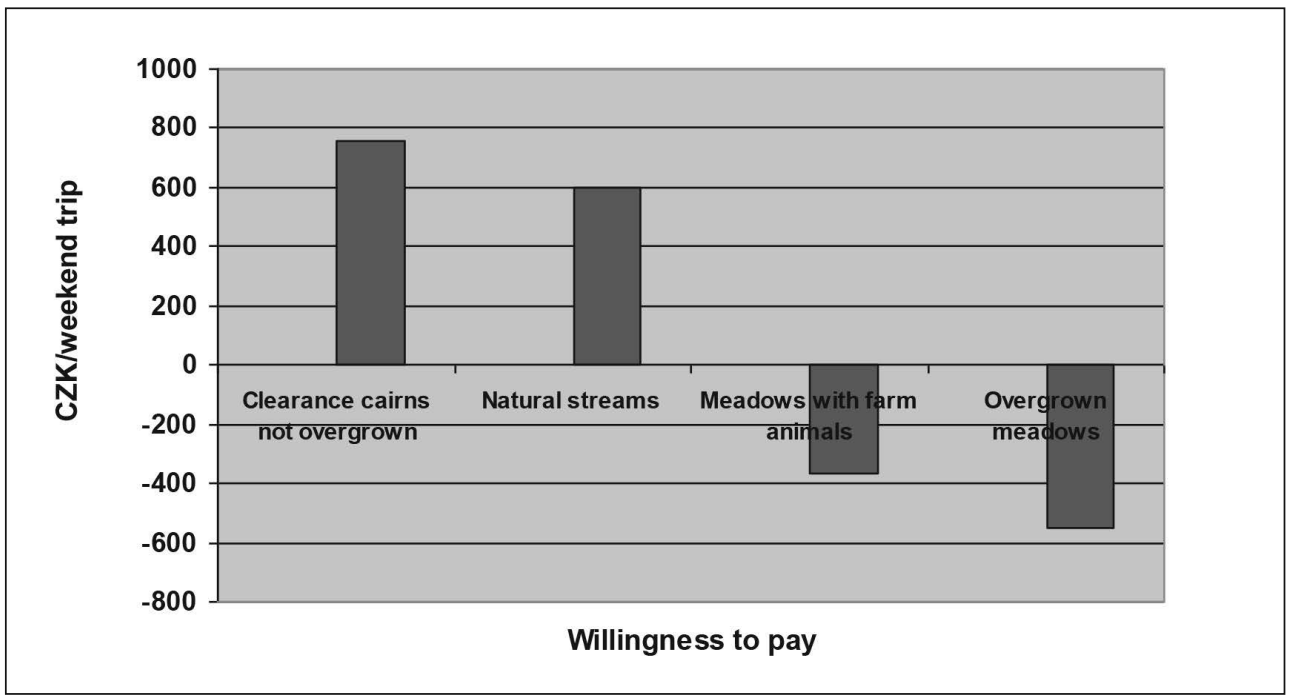

Source: own

As is evident from Fig. 2, the willingness to pay for clearance cairns is positive, amounting to CZK 757 per person per weekend-long trip. However, this value cannot be compared with results of international studies, as nobody has done detailed valuation of clearance cairns, or agrarian mounds. We came across a similar problem with the other examined biotopes. Foreign studies either deal with their valuation using the choice experiment method only marginally, or they work with other ecosystems (wetlands most frequently).

For the meadows, the attribute level "flowering meadows" was chosen as the baseline (it is therefore the imaginary zero willingness to pay and the willingness to pay for other levels of the attribute "meadows" is interpreted as a comparison with the willingness to pay for flowering meadows), which is why the interpretation is as follows: compared to flowering meadows, the willingness to pay for meadows used for grazing livestock is negative, amounting to CZK minus 365 per person and journey to the recreation site for a weekend-long trip. The willingness to pay for overgrown meadows (again, compared to flowering meadows) is also negative, amounting to CZK minus 552. As stated above, the survey also employed the contingent valuation method for the analysis of preferences concerning the montane meadows, the results of which are not presented in this paper in detail. However, to support the choice 
experiment results, let us at least state that $60 \%$ of the respondents would approve of an annual fee for preservation of the aesthetic function of the flowering montane meadows (presented in a scenario as a contribution towards maintenance of the meadows to prevent them from overgrowing over time). The average willingness to pay is CZK 452, which is very close to the choice experiment value of CZK 552. Admittedly, there are some foreign studies valuing ecosystem services of meadow ecosystems using the choice experiment method, but they are not montane meadows; most often, they are wet meadows and, above all, wetlands, which are substantially different from montane meadows in their character. To a certain extent, however, they provide similar ecosystem services, especially so-called cultural ecosystem services (recreational, aesthetic, educational, etc.). Choice experiment has been applied to these ecosystems by, e.g., Carlsson et al. (2003)., who found out in 2001 that provision of biodiversity and walking facilities are the greatest benefits of Swedish wetlands (the willingness to pay for a high degree of biodiversity: SEK 673 , for walking facilites: SEK 648). Birol et al. (2006) also used choice experiment to obtain information on the WTP for various attributes of Greek wetlands. The resulting WTP was EUR 15.10-15.62 for high biodiversity; EUR 9.86-11.02 for maintained wetlands not overgrown with reed, and EUR 8.6910.79 for space for study and research.

In the Eastern Ore Mountains, people are willing to pay CZK 599 for natural or quasinatural streams compared to regulated streams. Abroad, choice experiment has been applied to identify the WTP for improving river ecology by Hanley et al. (2006)., who examined how much people in the United Kingdom would be willing to pay for transforming a watercourse closer to its quasi-natural appearance (in particular, the study dealt with the Wear and Clyde rivers). The change would consist of several types of measures: (i) ecological measures: restoration of some less common fish species (salmon, trout), increasing the numbers of species of aquatic plants, insects and birds; (ii) aesthetic measures: removal of litter around the river; (iii) riverbank measures: increasing the numbers of trees on the riverbanks, return to purely natural erosion. The resulting WTP: (ii) GBP 18.19 for the ecological measures; (ii) GBP 15.68 for the aesthetic measures; (iii) GBP 19.57 for the riverbank measures.
The data was analysed for heterogeneity in the preferences using a random parameter logit model (Steer Davies Gleave, 2000). The sample of respondents was clustered according to their distance from the site of the interview (indicated in the questionnaire) and also other socioeconomic variables (respondent's age, sex, education etc.). The purpose of this clustering was to identify the difference in preferences among different group of people. The analysis did not reveal any significant heterogeneity regarding the respondents' residence distance. Most of the respondents belonged to the region (the distance was up to $30 \mathrm{~km}$ ). A different WTP regarding maintained clearance cairns and meadows with livestock was expressed by people coming from the capital Prague, but they represented only $9 \%$ of the respondents in the sample.

\section{Conclusions and Discussion}

The analysis results indicate that visitors to the Eastern Ore Mountains prefer a natural/ quasi-natural state of the landscape. The preferences among visitors to the study site are relatively unambiguous: the visitors clearly distinguished among various landscape forms, quite unambiguously preferring those options where the landscape was close to its contemporary state, i.e., montane meadows scythed without farm animals, clearance cairns not overgrown, and streams in the quasinatural state. These results were confirmed by both analysing the choice experiment data and analysing the contingent valuation method data; both the cases resulted in a significantly positive willingness to pay for the quasi-natural landscape condition.

At the same time, these results imply the confirmation of only some of the defined hypotheses. In particular, the hypotheses about quasi-natural streams and overgrowing meadows have been confirmed. The high preference of flowering meadows in contrast to the less positive valuation of meadows with livestock is in disagreement with the hypothesis, and our expectation, as is the result for the clearance cairns, where the hypothesis has not been confirmed: not only was the willingness to pay significant, but also very high in its monetary expression in the context of the other attributes. The last result is highly surprising and probably related to the fact that the larger part of the Czech visitors to the Eastern Ore Mountains are people from the near vicinity of the sites 
where the data collection took place. This is a relatively precious landscape element on the Czech Republic's scale and, as it turned out during the interviews, the locals associate the clearance cairns with their previous visits and often also with childhood memories. This leads us to the hypothesis that the clearance cairns contribute to local inhabitants' identification with the Eastern Ore Mountains landscape.

This hypothesis is also supported by the real situation in the Saxon part of the Eastern Ore Mountains, where locals regard the clearance cairns very highly. In fact every section of the clearance cairns has been mapped. The total length of the clearance cairns is close to one thousand kilometres. Compared to Saxony, the clearance cairns on the Czech side of the Ore Mountains receive only minimal attention. The differences in the attitude to this locally specific landscape element may be related to the different cultural and historical development in the region. In Saxony, this development has been continuous and the link between the landscape and the people has never been broken, whereas the development has been disrupted on the Czech side, where only the second local-born generation is now living (for more details about demographac development of Ustí nad Labem region see Kačírek, 2015). This context makes the present research results - the high willingness to pay for preserving the value and appearance of the clearance cairns in particular - even more interesting. It is evident that in spite of the disrupted cultural and historical link between the local people and the landscape, the clearance cairns are perceived as something locally specific and valuable.

As for the other examined ecosystems/ /biotopes, the resulting willingness to pay for their preservation in a good or quasi-natural condition is also relatively high. In connection with the ecosystem service theory and analysis, management of ecosystems and locally specific biotopes thus makes sense not only for environmental reasons - supporting ecosystem services (e.g., circulation of nutrients, soil formation), regulating services (e.g., water treatment, flood regulation), provisioning services (e.g., timber, forest fruit and game production) - but also for socio-economic reasons. The ecosystems analysed provide socalled cultural services (aesthetic, recreational and educational), which visitors to the sites regard highly and would even be willing to contribute hundreds of crowns a year towards their preservation. The results indicate that for local inhabitants, these specific biotopes (clearance cairns, montane meadows and quasi-natural mountain streams) are landscape elements that help them identify with the area and be proud of their region.

The authors believe that the present results may be (and should be) used to support decisionmaking about suitable and economically efficient methods of landscape management in the Eastern Ore Mountains (including long-term and strategic visions of landscape development in terms of environmental protection policy at both the local and regional levels). In this sense the valuation studies contribute to the support of decision making process and its results aiming at the economic efficiency.Different approach is represented by Šauer et al. (1998) and Fiala and Šauer (2011) by seeking for cost efficient ways of reaching the defined target in negotiation process (also under asymmetric information condition). On the other hand, the authors are well aware the fact that by environmental decission making process should be taken into account also the institutional settings of environmental governance to identify the implementation barriers and the acceptability of newly proposed environmental measures (more discussed by e.g. Slaviková, 2013).

Beyond the aforesaid, it is wise to mention that these are attractive tourist destinations, which if marketed appropriately might help develop tourism and, indirectly, support funding for the landscape maintenance and renewal. Generalising the research results, it can be concluded that the research has shown a positive link between the inhabitants and the landscape. In our opinion, this link should be developed and utilised for further development of the inhabitants' relationship with the landscape, which might contribute to naturally higher identification of the inhabitants with the regions and, among other things, contribute to spontaneously better protection of the environment and the components ecosystems (Slavíková et al., 2010). Engaging the public in environmental and biodiversity protection (e.g. by activities of NGOs) is seen as one of the ways, how to improve the environmental governance. According to Slavikova et al. (2017) environmental NGOs "may serve as effective complements of state biodiversity protection, especially when legally anchored 
in governance schemes and equipped with subsequent funding".

The research results can be used to promote functioning landscape management that will build on spontaneous environmental protection by local communities (which requires knowledge of their preferences and attitudes) as much as possible and, at the same time, respect the natural limits to the viable anthropogenic exploitation of the ecosystems (in ways that preserve the maximum of their natural ecosystem services).

The paper was written with support from the project "Value Nature of the Eastern Ore Mountains" (no. 100093854), implemented as part of the Cill 3/Ziel 3 scheme and co-funded from the European Regional Development Fund and partly also from the project "Cross border Flood Risk Management" (No. LE14010) financed from the programme EUPRO II (Czech Ministry of Education, Youth and Sport).

\section{References}

Agresti, A. (2013). Categorical Data Analysis. Hoboken, New Jersey: John Wiley \& Sons, Inc.

Albert, C., Galler, C., Hermes, J., Neuendorf, F., von Haaren, C., \& Lovett, A. (2016), Applying ecosystem services indicators in landscape planning and management. Ecological Indicators, 61, 100-113. doi:10.1016/j.ecolind.2015.03.029.

Bateman, I. et al. (2013). Bringing Ecosystem Services into Economic Decision-Making: Land Use in the United Kingdom. Science, 341(6141), 45-50. doi:10.1126/science.1234379.

Bateman, I. J., Carson, R. T., Hanemann, M., Hanley, N., Hett, T., Jones-Lee, M., Loomes, G., Mourato, S., Özdemiroğlu, E., Pearce, D. W., Sugden, R., \& Swanson, J. (2002). Economic Valuation with Stated Preference Techniques: A Manual. Cheltenham: Edward Elgar.

Birol, E., Karousakis, K., \& Koundari, P. (2006). Using a choice experiment to account for preference heterogeneity in wetland attributes: The case of Cheimaditida wetland in Greece. Ecological Economics, 60(1), 145-156. doi:10.1016/j.ecolecon.2006.06.002.

Braat, L. C., \& de Groot, R. S. (2012). The ecosystem services agenda: bridging the worlds of natural science and Economics, conservation and development, and public and private policy. Ecosystem Services, 1(1), 4-15. doi:10.1016/j.ecoser.2012.07.011.
Bryce, R., Irivne, K., Church, A., Fisch, R., Ranger, S., \& Kenter, J. (2016). Subjective wellbeing indicators for large-scale assessment of cultural ecosystem services. Ecosystem Services, 21, 258-269. doi:10.1016/j. ecoser.2016.07.015.

Carlsson, F., Frykblom, P., \& Liljenstolpe, C. (2003). Valuing wetland attributes: an application of choice experiments. Ecological Economics, 47(1), 95-103. doi:10.1016/j.ecolecon.2002.09.003.

Chan, K., Satterfield, T., \& Goldstein, J. (2012). Rethinking ecosystem services to better address and navigate cultural values. Ecological Economics, 74, 8-18. doi:10.1016/j. ecolecon.2011.11.011.

Chapman, J. C., Shiel, R. S., \& Batović, Š. (1987). Settlement Patterns and Land Use in Neothermal Dalmatia, Yugoslavia: 1983-1984 Seasons. Journal of Field Archaeology, 14(2), 123-146. doi:10.1179/009346987792208484.

De Vreese, R., Leys, M., Fontaine, C. M., \& Dendoncker, N. (2016). Social mapping of perceived ecosystem services supply The role of social landscape metrics and social hotspots for integrated ecosystem services assessment, landscape planning and management. Ecological Indicators, 66, 517-533. doi:10.1016/j.ecolind.2016.01.048.

Dickinson, D., \& Hobbs, R. (2017). Cultural ecosystem services: Characteristics, challenges and lessons for urban green space research. Ecosystem Services, 25, 179-194. doi:10.1016/j.ecoser.2017.04.014.

Farley, J. (2012). Ecosystem services: The economics debate. Ecosystem Services, 1(1), 40-49. doi:10.1016/j.ecoser.2012.07.002.

Fiala, P., \& Šauer, P. (2011). Aplikace kombinatorických aukcí na alokaci veřejných podpor v oblasti životního prostředí: ekonomický laboratorní experiment. Politická ekonomie, 69(3), 379-392. doi:10.18267/j.polek.797.

Freeman, A. M. (2003). The measurement of environmental and resource values: theory and methods. Washington, DC: Resources for the Future.

Gee, K., \& Burkhard, B. (2010). Cultural ecosystem services in the context of offshore wind farming: A case study from the west coast of Schleswig-Holstein. Ecological Complexity, 7(3), 349-358. doi:10.1016/j. ecocom.2010.02.008.

Greene, W. H. (2007). Econometric Analysis. Upper Saddle River, New Jersey: Prentice Hall. 
Groot, R. S. De, Alkemade, R., Braat, L. C., Heina, L., \& Willemen, L. (2010). Challenges in integrating the concept of ecosystem services and values in landscape planning, management and decision making. Ecological Complexity, 7(3), 260-272. doi:10.1016/j.ecocom.2009.10.006.

Haab, T. C., \& Mcconnell, K. E. (2003). Valuing Environmental and Natural Resources: the econometrics of non-market valuation. Cheltenham: Edward Elgar.

Hanemann, M. W. (1984). Welfare Evaluations in Contingent Valuation Experiments with Discrete Responses. American Journal of Agriculture Economics, 66(3), 332-341.

Hanley, N., Mourato, S., \& Wright, R. (2001). Choice modelling approaches: a superior alternative for environmental valuation? Journal of Economic Surveys, 15(3), 433-460. doi:10.1111/1467-6419.00145.

Hanley, N., Wright, R., \& AlvarezFarizo, B. (2006). Estimating the economic value of improvements in river ecology using choice experiments: an application to the water framework directive. Journal of Environmental Management, 78(2), 183-193. doi:10.1016/j.jenvman.2005.05.001.

Henscher, D. (1994). Stated preference analysis of travel choices: the state of practice. Transportation, 21(2), 107-133. doi:10.1007/BF01098788.

Kačírek, P. (2015). Demographic ageing in the old industrial regions - specifics and links on the example of the Ústí nad Labem Region (N Czechia). GeoScape, 9(1), 24-32. doi:10.1515/geosc-2015-0003.

Kenter, J., Hyde, T., Christie, M., \& Fazey, I. (2011). The importance of deliberation in valuing ecosystem services in developing countries - Evidence from the Solomon Islands. Global Environmental Change, 21(2), 505-521. doi:10.1016/j.gloenvcha.2011.01.001.

Kotíková, E. (2006). Ochrana životního prostředí v ekonomické teorii. Politická ekonomie, 54(2), 261-273. doi:10.18267/j.polek.557.

Kučera, L. (1994). Populace České republiky 1918-1991. Praha: Sociologický ústav Akademie věd České republiky.

Květon, V., Louda, J., Slavík, J., \& Pělucha, M. (2014) Contribution of Local Agenda 21 to Practical Implementation of Sustainable Development: The case of the Czech Republic. European Planning Studies, 22(3), 515-536. doi:10.1080/09654313.2012.753994.
Lancaster, K. (1966). A new approach to consumer theory. Journal of Political Economy, 74(2), 132-157. doi:10.1086/259131.

Layke, C., Mapendembe, A., Brown, C., Walpole, M., \& Winn., J. (2012). Indicators from the global and sub-global Millennium Ecosystem Assessments: An analysis and next steps. Ecological Indicators, 17, 77-87. doi:10.1016/j.ecolind.2011.04.025.

Lupp, G., Förster, B., Kantelberg, V., Markmann, T., Neumann, J., Honert, C., Koch, M., \& Pauleit, S. (2016). Assessing the Recreation Value of Urban Woodland Using the Ecosystem Service Approach in Two Forests in the Munich Metropolitan Region. Sustainability, 8(11), 1-14. doi:10.3390/su8111156.

Manski, C. F. (1977). The structure of random utility models. Theory and Decision, 8(3), 229-254. doi:10.1007/BF00133443.

McFadden, D. (1974). Conditional logit analysis of qualitative choice behaviour. In P. Zarembka (Ed.), Frontiers in econometrics. New York: Academic Press.

Millenium Ecosystem Assessment. (2005). Ecosystems and Human Well-being: synthesis. Washington, D. C.: Island Press.

Moravčík, P. (1994). Development of new forest stands after a large scale forest decline in the Krušné hory Mountains. Ecological Engineering, 3(1), 57-69. doi:10.1016/0925-8574(94)90012-4.

Palacios-Agundez, I., Onaindia, M., Barragueta, P., \& Madariaga, I. (2015). Provisioning ecosystem services supply and demand: The role of landscape management to reinforce supply and promote synergies with other ecosystem services. Land Use Policy, 47, 145-155. doi:10.1016/j.landusepol.2015.03.012.

Parsons, G. R. (1993). The Travel Cost Method. In P. A. Champ, K. J. Boyle, \& T. C. Brown (Eds.), A Primer on Nonmarket Valuation. London: Kluwer Academic Publishers.

Phaneuf, D. J., \& Smith, V. K. (2005). Recreation Demand Models. In K. G. Mäler, \& J. R. Vincent (Eds.), Handbook of Environmental Economics. Economywide and International Environmental Issues, 3 (pp. 1105-1618).

Primmer, E., \& Furman, E. (2012). Operationalising ecosystem service approaches for governance: Do measuring, mapping and valuing integrate sector-specific knowledge systems? Ecosystem Services, 1(1), 85-92. doi:10.1016/j.ecoser.2012.07.008. 
Půlpánová, L., \& Simová, J. (2012). Faktory spokojenosti zakazniku $v$ cestovnim ruchu. E\&M Ekonomie a Management, 15(4), 160-170.

Radvanovský, Z. (1993). Zur Vertreibung und Aussiedlung der Sudetendeutschen aus dem Grenzgebiet Nordwestböhmens in die sowjetische Besatzungszone Deutschlands in den Jahren 1945-1946. Ústi nad Labem: Albis International.

Rewitzer, S., Huber, R., Gert-Regamey, A., \& Barkmann, J. (2017). Economic valuation of cultural ecosystem service changes to a landscape in the Swiss Alps. Ecosystem services, 26, 197-208. doi:10.1016/j.ecoser.2017.06.014.

Ruijs, A., Wossink, A., Kortelainen, M., Alkemade, R., \& Schulp., C. J. E. (2013). Trade-off analysis of ecosystem services in Eastern Europe. Ecosystem Services, 2(4), 8294. doi:10.1016/j.ecoser.2013.04.002.

Slavík, J. (2007). Neoklasická ekonomie a ochrana životního prostředí. Politická ekonomie, 55(4), 526-537. doi:10.18267/j.polek.612.

Slavíková, L., Syrbe, R.-U., Slavík, J., \& Berens, A. (2017). Local environmental NGO roles in biodiversity governance: a CzechGerman comparison. GeoScape, 11(1), 1-15. doi:10.1515/geosc-2017-0001.

Slavíková, L. (2013). Na institucích záleží! Ale proč? Politická ekonomie, 61(1), 121-127. doi:10.18267/j.polek.887.

Slavíková, L., Šímová, T., \& Slavík, J. (2011). Kvalitativně orientované metody socioekonomického výzkumu a jejich využití v ekonomii životního prostředí. Ekonomický časopis, 59(8), 823-840.

Slavíková, L., Kluvánková-Oravská, T., \& Jílková, J. (2010). Bridging theoriesonenvironmental governance: Insights from free-market approaches and institutional ecological economics perspectives. Ecological Economics, 69(7), 1368-1372. doi:10.1016/j.ecolecon.2010.02.015.

Slezák, L. (2007). Pohraničí českých zemí na pokračování (Dosídlování v padesátých letech 20. st.). Acta Oeconomica Pragensia, 15(7), 383-394. doi:10.18267/j.aop.222.

Small, N., Munday, M., \& Durance, I. (2017). The challenge of valuating ecosystem servivces that have no material benefits. Global Environmental Change, 44, 57-67. doi:10.1016/j.gloenvcha.2017.03.005.

Stalhammar, S., \& Pedersen, E. (2017). Recreational cultural ecosystem services: How do people describe the value? Ecosystem Services, 26, 1-9. doi:10.1016/j.ecoser.2017.05.010.
Steer Davies Gleave. (2000). London Underground Customer Priorities Research. Report for London Underground.

Šauer, P., Dvořák, A., \& Fiala, P. (1998). Vyjednávání mezi autoritou a znečišt'ovateli jako model pro podporu rozhodování $v$ ekologické politice. Politická ekonomie, 46(6), 772-787. doi:10.18267/j.polek.258.

Šimková, E. (2008). Udržitelný rozvoj venkova a role venkovské turistiky. E\&M Ekonomie a Management, 11(1), 26-32.

Šimková, E. (2007). The Potential of Rural Tourism and the Sustainable Development of Rural Areas. E\&M Ekonomie a Management, 10(4), 57-62.

Tengberg, A., Fredholm, S., Eliasson, I., Knez, I., Saltzman, K., \& Wetterberg, O. (2012). Cultural ecosystem services provided by landscapes: Assessment of heritage values and identity. Ecosystem Services, 1(2), 14-26. doi:10.1016/j.ecoser.2012.07.006.

Train, K. (2009). Discrete Choice Methods with Simulation. New York: Cambridge University Press.

Vejchodská, E. (2015). Cost-benefit analysis: Too often biased. E\&M Ekonomie a Management, 18(4), 68-77. doi:10.15240/ tul/001/2015-4-005.

Vojáček, O., \& Pecáková, I. (2010). Comparison of discrete choice models for environmental research. Prague Economic Papers, 19(1), 35-53. doi:10.18267/j.pep.363.

Ing. Ondřej Vojáček, Ph.D.

Czech Technical University in Prague Department of Management and Economics and

Jan Evangelista Purkyně University in Ústí nad Labem

Faculty of Social and Economic Studies Institute for Economic and Environmental Policy ondrej.vojacek@gmail.com

Ing. Jiří Louda

Jan Evangelista Purkyně University in Ústí nad Labem

Faculty of Social and Economic Studies Institute for Economic and Environmental Policy and

Charles University Faculty of Humanities Department of Social and Cultural Ecology louda@ieep.cz 


\section{Abstract}

\section{ECONOMIC VALUE OF ECOSYSTEM SERVICES IN THE EASTERN ORE MOUNTAINS}

\section{Ondřej Vojáček, Jiří Louda}

The paper presents the results of a research project aiming at determining the economic value of selected ecosystem services in the Eastern Ore Mountains. The use of the dynamically evolving concept of economic services, used to identify economically utilisable services provided by undamaged ecosystems, can thus contribute to dealing with the issues of optimum landscape management. The primary data collection took place in the summer of 2013; a total of 216 questionnaires were collected. The research focused on three ecosystems, namely montane meadows, clearance cairns and quasi-natural mountain streams. The paper presents and discusses primarily the results of a choice experiment that was used to determine the willingness to pay for defined changes in the ecosystems examined. The research showed that visitors to the Eastern Ore Mountains unambiguously prefer a natural (authentic) or quasi-natural condition of the landscape and that people are able to distinguish among the different situations well (e.g., different appearance of montane meadows, mountain streams, clearance cairns, etc.). People prefer montane meadows scythed without farm animals, clearance cairns not overgrown, and streams with a quasi-natural character. The authors point out the finding that the research results indicate a strong connection of the local population to the local landscape and ecosystems, the potential of which in relation to nature protection and landscape management is totally unutilised at the moment. Special attention is paid to a specific ecosystem, not studied yet in the Czech Republic - the clearance cairns, which showed (contrary to expectations) a noticeably higher willingness to pay for their good management compared to the other ecosystems examined.

Key Words: Ecosystem services, economic valuation, choice experiment method, random utility theory, local ecosystems.

JEL Classification: C93, Q51, Q57.

DOI: 10.15240/tul/001/2017-3-001 